\title{
PRODUKSI HIJAUAN Indigofera zollingeriana YANG DIPUPUK MENGGUNAKAN FUNGI MIKORIZA ARBUSKULA PADA TANAH PASCA TAMBANG BATUBARA
}

\author{
Vio Lidya Wati ${ }^{1}$, Suharlina ${ }^{2}$, dan Imam Sanusi ${ }^{2}$ \\ ${ }^{1}$ Mahasiswa Program Studi Peternakan, Sekolah Tinggi Pertanian Kutai Timur, Kalimantan Timur \\ 2 Program Studi Peternakan, Sekolah Tinggi Pertanian Kutai Timur, Kalimantan Timur \\ Corresponding author: suharlina@stiperkutim.ac.id
}

\begin{abstract}
ABSTRAK
Lahan bekas pertambangan batubara merupakan tanah marginal yang dapat dimanfaatkan sebagai lahan tanaman pakan. Salah satu hijuan leguminosa yang berpotensi tumbuh di daerah marginal adalah Indigofera zollingeriana. Tujuan dari penelitian ini adalah untuk mengetahui pengaruh pemberian Fungi Mikoriza Arbuskula (FMA) terhadap produktivitas tanaman Indigofera zollingeriana pada tanah pasca tambang batubara. Penelitian menggunakan rancangan acak lengkap dengan 5 perlakuan yaitu o g FMA, 8 g FMA, 16 g FMA, 24 g FMA, 32 g FMA, dengan 5 ulangan. Peubah yang diamati meliputi profil daun, tinggi tanaman, dan produksi bahan kering daun dan tajuk. Data yang diperoleh dianalisis menggunakan analisis sidik ragam. Hasil penelitian menunjukkan bahwa tanaman Indigofera zollingeriana yang diberi FMA memiliki profil daun yang lebih hijau. Pemberian FMA menunjukkan pengaruh nyata terhadap produksi daun dan tajuk tetapi tidak berbeda nyata terhadap tinggi tanaman. Tanaman Indigofera zolllingeriana yang diberi FMA sebagnyak 16 g menunjukkan, produksi daun dan produksi tajuk yang lebih baik dibandingkan tanpa inokulasi FMA dan perlakuan lainnya.
\end{abstract}

Kata kunci: fungi mikoriza arbuskula, Indigofera zollingeriana, tanah pasca tambang batubara

\section{YIELD PRODUCTION OF Indigofera zollingeriana FERTILIZED USING ARBUSCULA MYCORRHYZA FUNGI IN POST COAL MINING LAND}

\begin{abstract}
Post mining land of coal is a marginal land that can be used as forages crop land. One of the legume trees that have the potential to grow up in marginal areas is Indigofera zollingeriana. The aim of this research was to find out the effect of Arbuscular Mycorrhizal Fungi (AMF) addition to Indigofera zollingeriana productivity in post mining land of coal. The completely randomized design were used in this study. There were 5 treatments with 5 replication, namely o g AMF, 8 g AMF, 16 g AMF, 24 g AMF, 32 g AMF, respectively. The variables observed were leaf profile, plant height, and dry matter production of plant canopy and leaf. The data were analyzed using analysis of variance. The results showed that Indigofera zollingeriana plants were fertilyzed by AMF had leaf colour profiles more greens than others. The addition of AMF showed a significant effect on leaf and shoot production but not significantly different on plant height. Indigofera zollingeriana plants treated with AMF as much as $16 \mathrm{~g}$ had better leaf production and shoot production than than the treatment without AMF addition.
\end{abstract}

Key words: Arbuscular Mycorrhizal Fungi, Indigofera zollingeriana, post mining land

\section{PENDAHULUAN}

Hijauan pakan merupakan faktor utama yang mempengaruhi perkembangan ternak ruminansia. Upaya penyediaan hijauan yang berkualitas dan berkesinambungan merupakan suatu masalah spesifik di Indonesia. Kabupaten Kutai Timur merupakan wilayah dengan potensi tambang batubara. Lahan bekas pertambangan batubara merupakan tanah marginal yang dapat dimanfaatkan sebagai lahan tanaman pakan, namun memiliki daya dukung yang rendah terhadap produktivitas hijauan pakan ternak. Upaya yang bisa digunakan untuk mengatasi masalah pada tanah marginal dan lahan pasca penambangan dapat dilakukan dengan penggunakan pupuk hayati antara lain fungi mikoriza arbuskula (FMA).

Manajemen pemberian pupuk sangat penting karena menentukan produksi, kualitas, dan kemampuan tumbuh kembali (regrowth) tanaman tersebut untuk menyediakan hijauan sebagai pakan yang berkuali- 
tas tinggi secara berkesinambungan. Lahan bekas penambangan batubara memiliki potensi besar untuk dimanfaatkan sebagai lahan penanaman hijauan pakan terutama leguminosa pohon. Leguminosa pohon juga berpotensi menyediakan pakan berkualitas sepanjang tahun. Salah satu hijuan leguminosa yang berpotensi tumbuh di daerah marginal adalah Indigofera zollingeriana. Indigofera zollingeriana memiliki pertumbuhan yang cepat dengan inerval defoliasi 60 hari dengan produksi hijauan mencapai 51 ton bahan kering ha $\mathrm{ha}^{-1} /$ tahun (Abdullah dan Suharlina, 2010). Indigofera zollingeriana sangat adaptif terhadap tingkat kesuburan rendah, mudah dipelihara murah, dan memiliki potensi produksi biji sepanjang musim (Abdullah, 2010).

Tujuan dari penelitian ini adalah nntuk mengetahui pengaruh pemberian Fungi Mikoriza Arbuskula (FMA) terhadap produksi hijauan Indigofera zollingeriana pada tanah pasca tambang batubara.

\section{METODE PENELITIAN}

Penelitian ini dilaksanakan mulai Desember 2019 sampai dengan April 2020 yang bertempat di lahan percobaan Jl Pendidikan Gg Bima Sangatta Utara, dan Laboratorium Nutrisi dan Teknologi Pakan STIPER Kutai Timur. Alat yang digunakan adalah thermohydrometer, polybag, timbangan, meteran, jangka sorong, tempat penampungan air (tandon), gayung, dan oven. Bahan yang digunakan adalah bibit Indigofera zillingeriana yang berumur 2 bulan, tanah pasca tambang batubara (tanah subsoil), pupuk kandang, air mineral, dan FMA. Bibit Indigofera zillingeriana yang diperoleh dari koleksi Laboratorium Nutrisi dan Tanaman Pakan STIPER Kutai Timur. FMA yang digunakan adalah mycofer yang diperoleh dari Laboratorium Bioteknologi Kehutanan, Pusat Penelitian Bioteknologi IPB.

Media tanam yang digunakan adalah kombinasi antara tanah pasca tambang batubara, dan pupuk kandang. Tanah pasca tambang batubara diperoleh dari lahan pasca tambang PT. Indexim Coalindo Kecamatan Kaliorang. Pupuk kandang yang digunakan sebanyak 35 ton/ha. Media semai dikering-anginkan kemudian disaring $5 \mathrm{~mm}$ agar struktur tanah seragam. Media tanah yang sudah seragam difumigasi dengan menggunakan larutan fungisida berbahan aktif dezomet 98\%. Kemudian diinkubasi selama dua minggu. Fumigasi bertujuan untuk mengkondisikan tanah menjadi steril, bebas dari mikoorganisme khususnya fungi.

Penelitian menggunakan rancangan acak lengkap (RAL) dengan 5 perlakuan yaitu inokulasi o g FMA (tanpa inokulasi FMA, kontrol), inokulasi 8, 16, 24, dan 32 g FMA per polybag. Tiap perlakuan meng- gunakan 5 ulangan.

\section{Prosedur Kerja}

Polybag (ukuran $10 \mathrm{~kg}$ ) diisi media tanah pasca tambang sebanyak $8 \mathrm{~kg}$, kemudian media tanah yang telah ditimbang kemudian dicampur dengan pupuk kandang sebanyak 140 gram. Semua bibit disterililasi menggunakan fungisida $1 \mathrm{ml} / 50 \mathrm{ml}$ air mineral selama 5-10 menit kemudian ditanam pada media. FMA diberikan sesuai perlakuan (o, 8, 16, 24, dan 32 gram FMA) untuk setiap polybag yang diletakan dekat akar Indigofera zollingriana. Penyiraman dilakukan sehari 2 kali menggunakan air hujan sebanyak $500 \mathrm{ml}$, jika terjadi hujan maka tidak dilakukan penyiraman.

Pengukuran tinggi tanaman dilakukan satu minggu sekali. Defoliasi dilakukan setelah 60 hari dengan memotong tanaman Indigofera zolingeriana dari bagian bawah mendekati permukaan tanah, kemudian dilakukan penimbangan tajuk dan daun. Sampel yang sudah ditimbang dikeringanginkan selama 3 hari untuk mengurangi kadar air. Pengeringan sampel menggunakan oven dengan suhu $60^{\circ} \mathrm{C}$ selama 48 jam. Setelah 48 jam, sampel dikeluarkan dan ditimbang untuk diketahui kadar air yang hilang. Kadar air oven 60 dihitung dengan rumus berikut:

$$
\begin{aligned}
& \mathrm{KA}_{60}=\frac{\mathrm{a}-\mathrm{b}}{\mathrm{a}} \times 100 \% \\
& \text { Keterangan: } \\
& \mathrm{KA}_{60}: \text { Kadar............ } \\
& \mathrm{A} \quad: \text { Bobot sampel awal (segar) } \\
& \mathrm{B} \quad: \text { Bobot sampel setelah oven } 60^{\circ} \mathrm{C}
\end{aligned}
$$

Sampel yang sudah dikeringkan dengan oven $60^{\circ} \mathrm{C}$ digiling halus dengan ukuran partikel $1 \mathrm{~mm}$. Penetapan kadar air menggunakan metode AOAC (2005). Analisis kadar air menggunakan oven dengan suhu $105^{\circ} \mathrm{C}$. Cawan yang bersih dimasukkan dalam oven pada suhu $105^{\circ} \mathrm{C}$ selama $1 \mathrm{jam}$, kemudian didinginkan dalam desikator dan ditimbang (a gram). Sampel sebanyak \pm 3 gram dimasukkan dalam cawan dan ditimbang ( $b$ gram). Cawan yang sudah berisi sampel dan diketahui bobotnya dimasukkan ke dalam oven pada suhu $105^{\circ} \mathrm{C}$ selama 6 jam. Setelah 6 jam sampel didinginkan dalam desikator dan ditimbang (c gram). Setelah itu cawan dan sample dimasukkan kembali ke dalam oven pada suhu suhu $105^{\circ} \mathrm{C}$ selama 1 jam. Kemudian cawan yang berisi sampel didinginkan dalam desikator dan ditimbang kembali sampai menghasilkan bobot tetap. Kadar air dihitung berdasarkan rumus sebagai berikut:

$$
\mathrm{KA}_{105}=\frac{(\mathrm{b}-\mathrm{a})-(\mathrm{c}-\mathrm{a})}{\mathrm{a}} \times 100 \%
$$


Keterangan

KA105: Kadar air 1050C

A : Bobot cawan kosong

B : Bobot sampel sebelum dimasukkan oven 1050C

C : Bobot cawan dan sampel setelah oven $1050 \mathrm{C}$

Perhitungan kadar air total pada bahan segar mengikuti metode Askar dan Darwinsyah (1985) dengan rumus:

$$
\mathrm{Z}=\mathrm{X}+\frac{(100-\mathrm{X}) \mathrm{Y}}{100}
$$

Keterangan:

$\begin{array}{ll}\mathrm{Z} & : \text { Kadar air total } \\ \mathrm{X} & : \text { Kadar air setelah oven } 600 \mathrm{C} \\ \mathrm{Y} & : \text { Kadar air setelah oven } 1050 \mathrm{C}\end{array}$

Kadar bahan kering total dihitung dengan dengan rumus sebagai berikut:

$$
\mathrm{BK}_{\text {total }}=100-\text { Kadar air total }
$$

Peubah yang diamati yaitu 1) Profil daun, pengambilan data dilakukan dengan cara pengamatan warna daun; 2) Tinggi tanaman, pengambilan data dilakukan dengan cara mengukur tanaman dari atas permukaan tanah sampai ke bagian pucuk tanaman menggunakan meteran; 3) Produksi bahan kering daun dan tajuk merupakan hasil perkalian persentase bahan kering (\%BK) dengan bobot daun dan tajuk tanaman segar.

\section{Analisis Data}

Data yang telah diperoleh kemudian diolah dengan analisis sidik ragam (uji F) (Sastrosupadi, 2000), dengan rumus sebagai berikut:

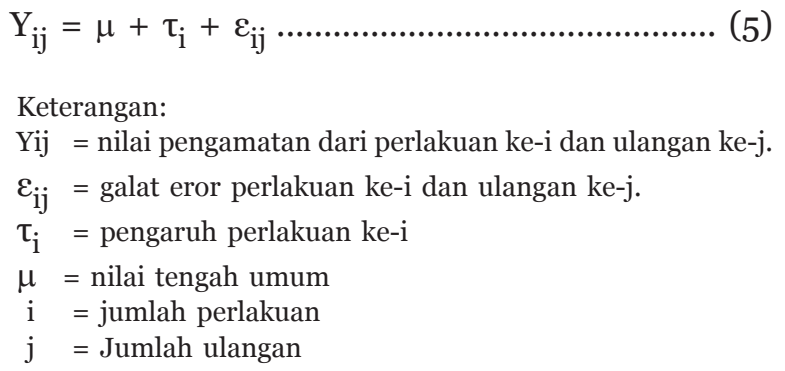

Apabila terdapat hasil uji menunjukkan pengaruh nyata, maka dilakukan uji lanjut menggunakan BNT (Beda Nyata Terkecil).

\section{HASIL DAN PEMBAHASAN}

\section{Profil Daun}

Pemberian pupuk FMA berpengaruh terhadap profil daun pada tanaman Indigofera zollingeriana (Gambar 1). Pemberian FMA pada taraf o\% menunjukkan warna daun yang lebih kuning dibandingkan daun yang diberi FMA, daun yang berwarna kuning mengindikasikan gejala kekurangan nutrien, terutama protein. Kekurangan nitrogen akan menyebabkan pertumbuhan terhambat, daun berwarna kuning, dan warna hijau daun menjadi pucat (Lingga, 1998). Sedangkan daun yang telah diinokulasi FMA menunjukkan bahwa tanaman lebih kaya unsur nitrogen (N) dengan ciri daun berwarna lebih hijau. Hal ini sesuai dengan pendapat Suharlina (2010) tanaman yang banyak mendapatkan nitrogen biasanya mempunyai daun yang hijau dan lebat. Bertambahnya unsur nitrogen $(\mathrm{N})$ dalam tanaman berasosiasi dengan pembentukan klorofil di daun sehingga meningkatkan proses fotosintesis (Widayanti, 2008).

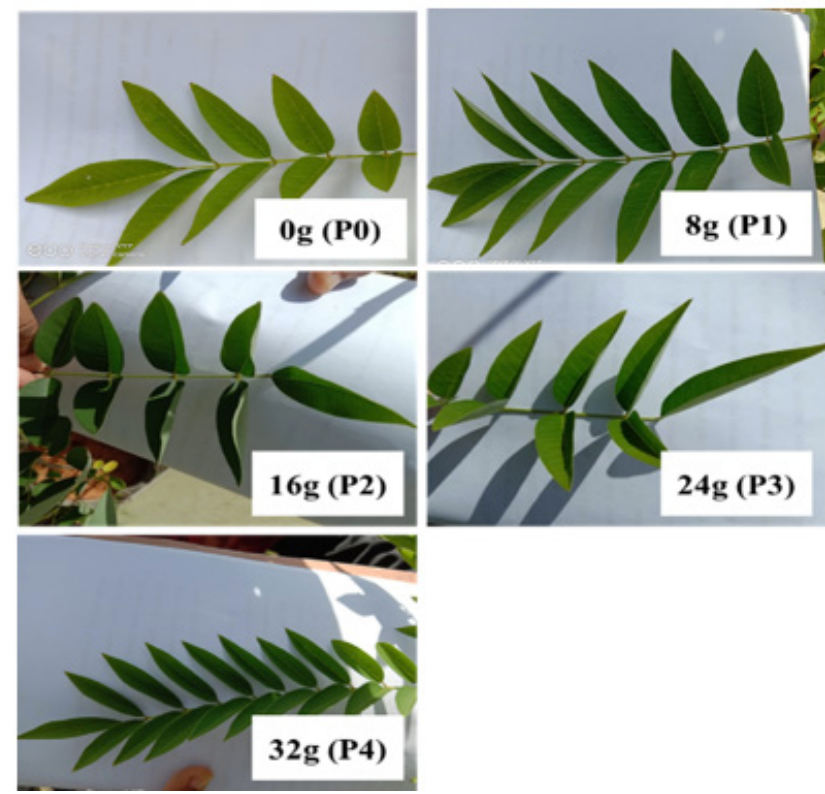

Gambar 1 Profil daun Indigofera zollingeriana yang diberi pupuk Fungi Mikoriza Arbuskula

\section{Pertumbuhan Tanaman Indigofera zollinge- riana Pertambahan Tinggi Tanaman}

Tinggi tanaman merupakan ukuran tanaman yang sering diamati baik sebagai indikator pertumbuhan maupun sebagai parameter yang digunakan untuk mengukur pengaruh lingkungan atau perlakuan yang diterapkan (Sitompul dan Guritno, 1995). Lakitan (1996) menyatakan tinggi tanaman merupakan indikator pertumbuhan yang paling mudah diukur. Pertumbuhan suatu tanaman merupakan hasil dari metabolisme sel-sel hidup yang dapat diukur secara kuantitatif, seperti pengukuran tinggi tanaman. Hasil pegukuran pertumbuhan tinggi tanaman pada saat penelitian dapat dilihat pada (Tabel 1) menjelaskan bahwa pemberian dosis FMA tidak berbeda nyata. Ini disebabkan pada masa awal pertumbuhan atau dalam fase vegetatif awal tanaman masih mengalami adaptasi dengan lingkungan dan kandungan hara tanah sehingga FMA belum berpengaruh terhadap tinggi 
Tabel 1. Pertumbuhan Tanaman Indigofera zollingeriana yang Diberi FMA

\begin{tabular}{|c|c|c|c|c|c|}
\hline & \multicolumn{5}{|c|}{ Perlakuan } \\
\hline & Po & P1 & $\mathrm{P} 2$ & $\mathrm{P}_{3}$ & $\mathrm{P}_{4}$ \\
\hline Pertambahan tinggi tanaman $(\mathrm{cm})$ & $11,49 \pm 6,60$ & $17,60 \pm 8,02$ & $17,40 \pm 6,07$ & $16,60 \pm 8,20$ & $18,80 \pm 10,83$ \\
\hline Produksi daun (Kg/ha) & $4,21 \pm 4,21^{b}$ & $5,72 \pm 1,5 \mathrm{O}^{\mathrm{ab}}$ & $7,46 \pm 1,60^{\mathrm{a}}$ & $5,78 \pm 1,05^{\mathrm{ab}}$ & $5,21 \pm 0,84^{\mathrm{ab}}$ \\
\hline Produksi tajuk (Kg/ha) & $5,04 \pm 1,54^{\mathrm{b}}$ & $6,80 \pm 1,92^{\mathrm{ab}}$ & $8,74 \pm 1,87^{\mathrm{a}}$ & $6,81 \pm 1,13^{\mathrm{ab}}$ & $6,35 \pm 0,82^{b}$ \\
\hline
\end{tabular}

Keterangan: superskrip yang berbeda pada baris yang sama menunjukkan perbedaan yang nyata $(\mathrm{P}<0,05)$

tanaman. Hal ini berbeda dengan pernyataan Zhang et al. (2011) yaitu tanaman yang diinokulasi FMA memiliki tinggi tanaman yang lebih baik dibanding tanaman yang tidak diinokulasi oleh FMA, dan aplikasi FMA dalam tanah lapang dan menggunakan dosis pupuk organik yang optimal sangat meningkatkan pertumbuhan dan serapan hara.

\section{Produksi Bahan Kering Daun}

Daun dipandang sebagi produsen fotosintat utama sehingga pengamatan daun sangat diperlukan selain sebagai indikator pertumbuhan juga sebagai data penunjang untuk menjelaskan proses pertumbuhan yang terjadi seperti pada pembentukan biomasa tanaman. Jumlah daun seringkali berkorelasi positif terhadap pertumbuhan dan produktivitas (Sitompul dan Guritno, 1995). Berdasarkan Tabel 1 dapat dijelaskan bahwa inokulasi FMA berpengaruh nyata terhadap produksi daun dengan inokulasi FMA sebanyak 16 g. Hal ini dapat dijelaskan bahwa FMA dapat meningkatkan penyerapan unsur hara pada tanaman, terutama nitrogen $(\mathrm{N})$. Bertambahnya unsur $\mathrm{N}$ dalam tanaman berasosiasi dengan pembentukan klorofil di daun sehingga meningkatkan proses fotosintesis yang memacu pertumbuhan jumlah daun tanaman (Widayanti, 2008). Hal ini juga sesuai dengan dengan pendapat Xie et al. (2014) yang menyatakan bahwa inokulasi FMA dapat meningkatkan penyerapan unsur hara $\mathrm{N}$ oleh akar tanaman, sehingga unsur hara $\mathrm{N}$ yang tersedia pada media diserap secara optimal oleh akar yang bermikoriza.

\section{Produksi Bahan Kering Tajuk}

Hasil analisis yang telah dilakukan menunjukan adanya pengaruh nyata pada taraf pemberian fungi mikoriza arbuskula sebanyak $16 \mathrm{~g}$ terhadap produksi tajuk (Tabel 1). Produksi tajuk ditandai dengan panjang batang dan jumlah daun, maka semakin banyak jumlah daun dan panjang batang menandakan produksi tajuk yang baik. Hal ini dapat dihubungkan dengan semakin meningkatnya penyerapan hara dan air yang diedarkan keseluruh organ tanaman dan dapat membantu ketersediaan bahan baku proses fotosintesis. FMA dapat menstimulasi pembentukan hormon seperti auksin, stitokinin dan giberelin yang berfungsi sebagai perangsang pertumbuhan tanaman (Anas 1997).
FMA mampu meningkatkan penyerapan unsur hara pada tanaman yang berpengaruh terhadap peningkatan pertumbuhan dan perkembangan organ vegetatif seperti tajuk. Unsur hara, air, dan cahaya diperlukan oleh tanaman untuk pertumbuhan yang kemudian akan dialokasikan dalam bentuk bahan kering selama fase pertumbuhan (Gardner 1985). Berat kering tajuk merupakan efisiensi proses fotosintesis, dimana semakin besar fotosintat yang dihasilkan maka semakin besar berat kering yang dihasilkan. Semakin berat bobot kering tanaman, maka pertumbuhan tanaman tersebut semakin baik dan unsur hara serta air yang terserap tanaman juga semakin banyak (Musfal, 2010) ditambah dengan pendapat Karti et al. (2012) bahwa pemberian FMA dapat meningkatkan berat kering tajuk dan akar.

\section{SIMPULAN DAN SARAN}

Pemberian Fungi Mikoriza Arbuskula (FMA) pada tanaman Indigofera zollingeriana yang diberi FMA menunjukkan profil tanaman yang lebih hijau. Tanaman Indigofera zollingeriana yang diberi FMA sebanyak 16 g menunjukkan, produksi daun dan produksi tajuk yang lebih baik dibandingkan tanpa inokulasi FMA.

\section{DAFTAR PUSTAKA}

Abdullah, L, dan Suharlina. 2010. Herbage Yield and Quality of Two Vegetative Parts of Indigofera at Different Times of First Regrowth Defoliation. Media Peternakan.

Abdullah, L. 2010. Herbage Production and Quality of Shrub Indigofera Treated by Different Concentration of Foliar Fertilizer. Media Peternakan.

AOAC 2005. Oficial methods of analysis of the Association of Analytical Chemist Virginia USA. Association of Official Analitykal Chemist, Inc

Anas I. 1997. Bioteknologi Tanah. Laboratorium Biologi Tanah Jurusan Tanah Fakultas Pertanian, IPB.

Gardner, FP, Pearce RB, Mitchel Rl. 1985. Physiology of Crop Plants.Diterjemahkan oleh Susilo H. dengan judul Fisiologi Tanaman Budidaya. Universitas Indonesia, Jakarta. 
Karti, P. D. M. H, D. A. Astuti, and S. Nofyangtri 2012. The role of arbuskular mycorrhizal fungi in enhancing productivity, nutritional quality, and droughttolerance mechanism of Stylosanthes seabrana.

Lakitan, B. 1996. Fisiologi Tumbuhan dan Perkembangan Tanaman. PT. Raja Grafindo Persada, Jakarta.

Martoyo, K. 2001.Sifat Fisik tanah Ultisol pada Penyebaran Akar tanaman Warta PPKS.

Musfal. 2010. Potensi cendawan mikoriza arbuskula untuk meningkatkan hasil tanaman jagung. J. Litbang Pertanian Vol.29 No.4

Salisbury, F. B., and C. W. Ross. 1995. Fisiologi Tumbuhan. Jilid 2. Penerbit ITB Bandung, Bandung.

Sastrosupadi, A. 2000. Rancangan Percobaan Praktis Bidang Pertanian. Buku. Kanisius. Malang.

Simarmata, T. 2004. Teknologi Pupuk Organik. Dalam Akyas, A.M. T. Pudjianto, T. Simarmata, D. Widayat dan C. Tjahyadi (Eds). Penulisan Budidaya Buahbuahan (Mangga). Dirjen Tanaman Pangan, Departemen Pertanian
Suharlina. 2010. Peningkatan Produktivitas Indigofera sp. sebagai Pakan Hijauan Berkualitas Tinggi Melalui Aplikasi Pupuk Organik Cair dari Limbah Industry Penyedap Masakan.

Widayanti, A. 2008. Efek pemotongan dan pemupukan terhadap produksi dan kualitas Borreria alata (Aubl.) sebagai hijauan makanan ternak kualitas tinggi. Skripsi. Fakultas Peretnakan. Institut Pertanian Bogor, Bogor.

Wong, C. C, F Moog, and C. P. Chen. 2005 Forage and Ruminant Livestock Integrations in Tree Crop Plantations of Sou the ast Asia in: Reynold S.G. and J. Frame (Eds) Grasslands Developments, Opportunitles, Prespectives Science Publishers, Inc. Enfield, New Hampshire.

Xie, X, B. Wong B. Cai, Y. Dong dan C. Yan. 2014. Effects of Arbuscular inoculation and phosphorus supplyon the growth and nutrient uptake of Kandelia obovate (Sheue, Liu and Yong) seedlings in autoclaved soil.

Zhang, G. Y., L. P.Zhang, M. F. Wei, Z. Liu, Q. L. Fan, Q. R. Shen, and G. H. Xu. 2011. Effect of arbuscular mycorrhizal fungi, organic fertilizer and soil sterilization on maize growth. J. Acta Eco. Sinica. 